\title{
Integrated Approach for Assessing the Economic Security of a Cluster
}

\author{
Andrey Polyanin ${ }^{1}$, Lyudmila Pronyaeva ${ }^{1 *}$, Anna Pavlova ${ }^{1}$, Olga Fedotenkova ${ }^{1}$, Dmitry \\ Rodionov $^{2}$ \\ ${ }^{1}$ Department of Management and Public Administration Central Russian Institute of Management, Branch of \\ RANEPA Orel, 302028, Russia \\ ${ }^{2}$ Institute of Industrial Management, Economics and Trade, Peter the Great St. Petersburg Polytechnic University, \\ Staint Petersburg 195251, Russia
}

\begin{abstract}
The aim of the study is to develop scientific and methodological recommendations that can contribute to the timely identification of real and potential economic threats in a cluster. In present-day conditions, clusterization is one of the most effective ways to overcome systemic challenges and crisis phenomena in the economy. Integration of independent organizations into clusters, based on principles of localization, integration and synergy, has the purpose of increasing their competitiveness. At the same time, cluster functioning is connected to various risks and threats that reduce sustainable development and affect the level of economic security of both the cluster and its participants. During the research, general scientific methods, such as the generalization, synthesis and analysis of the accumulated scientific results were evaluated in terms of ensuring the economic security of organizations, including their cluster. A number of techniques and methods were applied to develop the proposed integrated approach to assessing the economic security of clusters: typology, identification, rating-and-scores, and the indicative method. A critical assessment of the existing methods for assessing the economic security of clusters was given. It was revealed that the main drawback of these methods is that they do not consider the complicated internal management structure of a cluster. We created a methodology for assessing the economic security of a cluster, which is characterized by a comprehensive approach considering all the possible risks and threats in the functioning of the individual components of the cluster structure.
\end{abstract}

Keywords: Cluster; Comprehensive assessment; Economic security; Indicators; Risks

\section{Introduction}

Currently, the economies all countries face many systemic challenges arising from the restructuring of the world economy, increasing global competition and crisis phenomena. To overcome these challenges, different approaches are used to ensure the economic growth, sustainable development and economic security of a country and its regions. One of these approaches is clusterization of the economy. This approach can be applied to, comprehensively solve the tasks related to economic development, such as increasing the competitiveness of the enterprises, territories, and industries, the effectiveness of regional economic policy and its level of economic security. There is no doubt that an axiom proved by many scientists is that the cluster approach, based on the well-known principles of localization, integration and synergy, ensures the economic security of the cluster territory. 
Issues, such as establishing the cluster approach, justifying of the advantages of a cluster form of integration, identifying the cluster types and determining how to identify them in the economy, the forming and implementing the cluster policy, have been presented in the works of cluster theory founder Porter (1998) and his followers (Roelandt and Hertog, 1999; Sölvell et al., 2003; Anderson et al., 2004). The studies of Jacobs and de Man (1996) substantiated a functional structure of a cluster and presented the types of cluster bonds.

A number of scholars have proven that the participation of companies in a cluster allows for better exchange, acquisition and generation of new knowledge, which is - the basis of competitiveness (Beaudry and Breschi, 2003; Malmberg and Power, 2005). Studies by other scholars have shown that cluster member firms have higher survival rates and performance indicators than similar companies outside the clusters (Wennberg and Lindqvist, 2010; Delgado et al., 2014).

A number of interesting scientific studies have been conducted to develop a methodology for assessing the functioning of clusters, such as: a methodology for assessing the level of development of a regional cluster in the information technology (IT) sector to identify the prerequisites for the formation of a digital cluster in the region based on an integral indicator (Kudryavtseva et al., 2020); a multivariate model for assessing the impact of the joint actions of cluster members on their productivity and transfer of innovations (Wiratmadja et al., 2016); and a port cluster development model based on tandem free trade policies and coastal ecosystem preservation (Moeis et al., 2020).

In the field of economics, the problem of ensuring the economic security of a cluster remains ultimately undeveloped in terms of theoretical and methodological aspects and scientific and methodological recommendations, as determined by a combination of the conditions and factors that ensure the cluster's ability to pursue the sustainable growth of the well-being of its participants.

The theoretical grounds for assessing economic security are rooted in the writings of United States (US) scholars. For example, Nanto (2011) studied the influence of state policy on the economy: defining the state policy role in the creation of the conditions for economic security at different levels. Buzan (1991) substantiated the relationship between economic security insurance and economic stability and sustainability. While researching the problems of spatial socio-economic interregional inequality, Lessman (2013) identified it as a serious threat to the economic security of territories.

In Russia, Senchagov (2007) is a universally acknowledged theorist of economic security, who introduced the concept of economic security, and defined its categories, indicators and their threshold values. Significant research in the field of the categorization of threats to economic security was conducted by of Afontsev (2001). Other studies started featuring some interesting approaches to the classification of external and internal threats to economic security in clusters. Specifically Klimonova and Yurina (2014)- emphasized the threats of the manifestation of globalization in the field of economic security of the cluster, Nosov (2018) - identified additional threats to the economic security of an enterprise - a member of the cluster, Plotnikov (2015) - systematized the risks of cluster policy by subject composition, and Izmalkova and Vertakova (2019) - proposed a system of risk-oriented diagnostic indicators of an enterprise of a cluster structure.

In their scientific study, Podmolodina et al. (2012) proposed a system of methods for assessing the economic security of an enterprise, making it possible to draw conclusions about its ability to withstand external and internal threats. Sergeeva and Chunaev (2019), proposed a model for diagnosing economic security at the level of enterprises based on an analysis of the existing methods for its assessment. 
However, only a few scientific papers have presented specific methods for assessing the cluster's economic security. Thus, Ermolaev (2014) grounded his methodology for a comprehensive assessment of the cluster's economic security on the assessment of the economic security of enterprises that participate in this integrated structure. For each type of security (personnel, environmental, strategic, corporate, security of the state of economic efficiency of production, etc.), Ermolaev (2014) defined a key indicator. However, in our opinion, a disadvantage of this approach is that it does not assess the economic security of the entire cluster structure.

The essence of the methodology for assessing the competitiveness and sustainability of clusters proposed by Gakashev (2013) is that successful clusters have a stable (leading) position in the market based on their innovative technological superiority over other manufacturers of the cluster's product. Gakashev (2013) highlighted three main positions with a set of indicators: a market position, technological leadership, and the ability to upgrade. We consider this methodology as being effective for characterizing the degree to which the cluster development is successful, but it can only be part of an integrated methodology for assessing the economic security of a cluster.

A methodology proposed by Polyutov (2009) is based on determining the level of economic security of a cluster by calculating a number of indicators that characterize the security and efficiency of the cluster participants. However, a structure of these indicators does not imply the possibility of conducting a comprehensive assessment of the economic security of a cluster; it is mainly focused on assessing the effectiveness of its participants' management.

While assessing the above-mentioned methods, we should note that there is no integrated approach that would allow for assessing the economic security of a cluster with its complex integrated structure. In our opinion, the integrity of the approach to assessing the economic security of a cluster should consist of assessing the separate components of the cluster structure: the level of the cluster's management system and the level of the enterprises participating in the cluster association.

\section{Methods}

To conduct in-depth research of previous studies on the issue of assessing the economic security of clusters, we used general scientific methods, such as generalization, synthesis, and analysis of the accumulated scientific results in terms of ensuring the economic security of organizations, including their cluster associations.

When developing an integrated approach to assessing the economic security of clusters, we used a synthesized approach based on a combination of a resource-functional method (to determine the types of economic security for each level of the cluster structure), the principles of program-targeted management (to create a list of indicators characterizing the economic security of the levels of the cluster structure), a rating method, and general analysis techniques (to compare the actual values of the indicators of the economic security of the clusters with their indicators (threshold values). To conduct a quantitative assessment of the economic security for the level of the cluster's management system, we used an indicative and a rating-and-score method, the combination of which allows us to identify the drawbacks in the cluster functioning and to determine the most effective methods for eliminating those drawbacks.

\section{Results and Discussion}

The economic security of a cluster association is the condition under which a favorable environment is created for its participants, which ensures the competitiveness and increase 
the efficiency of the participants' activities.

As the clusters grow, an increasing volume of internal and external communications makes each of the participants more vulnerable, for example, in terms of information security. The importance of assessing the economic security of a cluster is also determined by a deep integration of the enterprises that are members of the cluster. If specific problems arise in one member of the cluster association, the consequences of this problem may affect the other participants (Kudrevich et al., 2020).

Various methods can be used to assess the level of economic security, including those based on a resource-functional approach, on the principles of program-targeted management, and on the rating assessment.

The first method is based on the assessment of how the resources of an economic entity are used in the main operational areas of activity; it assumes that the more efficiently the resources are used, the higher the level of economic security. The second method, the assessment of economic security, is based on the calculation of a set of integrated indicators that determine its level. The third approach is grounded on comparing the amount of investments of an economic entity with the amount of funds needed to ensure its economic security. Evaluation of the level of economic security of a cluster should be carried out by comparing the actual and threshold values of the economic security figures (indicators), which gives a quantitative definiteness to the results of the analysis.

In the course of this study, we put forward the assumption based on a synthesis of the existing approaches and our own research (Polyanin et al., 2018) that the presence of a methodologically secured integrated approach will make it possible to assess the economic security of a cluster with its complex, integrated structure. At the same time, the complexity of our proposed approach to assessing the economic security of a cluster consists of assessing the individual components of the cluster structure (the level of the cluster's management system and the level of the enterprises participating in the cluster association) in the context of the types of economic security, which distinguishes this study from similar ones.

A sequence of assessing the level of economic security of a cluster lies in determining the types of economic security for each level of its structure, drawing up a list of indicators characterizing the economic security of the structure levels, determining the indicators of economic security, analyzing and comparing the actual values with their indicators (thresholds), detecting and analyzing the obtained deviations, ranking the actual threat levels based on the thresholds, and determining the integral indicator of the economic security of a cluster.

The indicators characterizing the components of economic security (P 1...Pan) and the integral indicators for the components of economic security (J), as indicated in Figure Number1, are detailed in the tables below.

The complex approach we suggest allows us to obtain a cumulative integral indicator of the economic security of a cluster. At the same time, the assessment of the economic security components based on the levels of the cluster structure makes it possible to estimate the existing threats in the functioning of a cluster association, determine the source of these threats, and select preventive measures to eliminate it. This approach is schematically shown in Figure 1.

The calculation of a cumulative integral indicator of the cluster's level of economic security allows us to track some trends in its changes, as well as to make comparative estimates of the level of economic security of the clusters that have the same industry specialization. Summing of the scores and dividing of the obtained value by the maximum 
value in the scores by the type of economic security of the cluster enable us to calculate the general integral indicators.

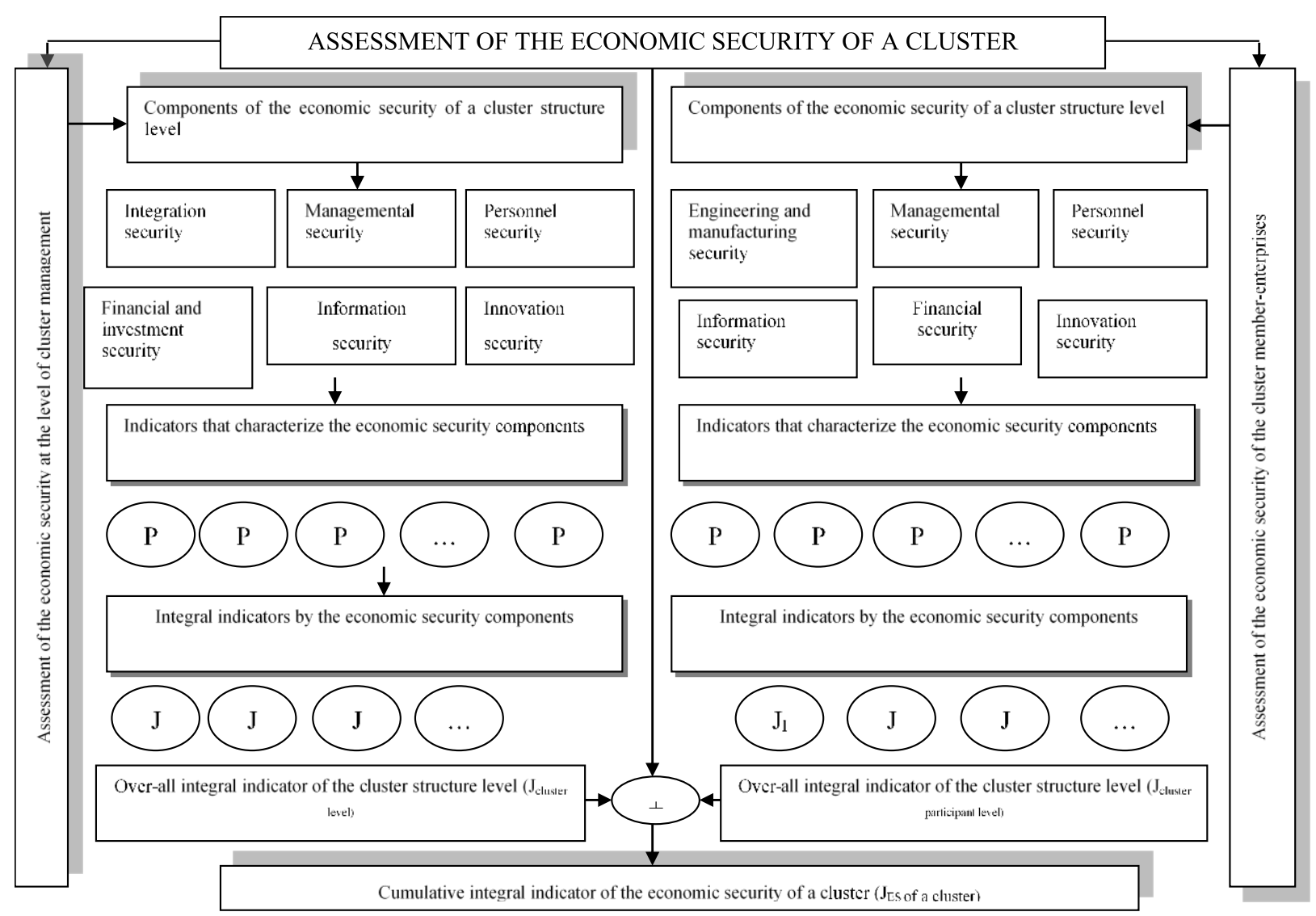

Figure 1 Complex approach to the cluster's economic security assessment

Table 1 presents the composition of the values, their indicators, and an example of how to calculate an integral indicator for the integration safety at the level of cluster management. If necessary, the composition of the proposed indicators by types of threats to economic security can be expanded.

Table 1 Composition of values and their indicators for integral security of the cluster management level

\begin{tabular}{|c|c|c|c|c|}
\hline Indicator's name & Threshold value & $\begin{array}{c}\text { Indicator's } \\
\text { value }\end{array}$ & $\begin{array}{c}\text { Actual } \\
\text { indicator }\end{array}$ & Indicator \\
\hline \multicolumn{5}{|c|}{ Type of threat to economic security } \\
\hline \multicolumn{5}{|c|}{ Instability of integration interaction } \\
\hline $\begin{array}{l}\text { Dynamics in the number of enterprises } \\
\text { participating in the cluster }\end{array}$ & $\begin{array}{c}>110 \% ; 100-110 \% \\
<100 \%\end{array}$ & $1 ; 0.5 ; 0$ & 108 & 0.5 \\
\hline $\begin{array}{l}\text { Dynamics in the number of employees in the } \\
\text { cluster }\end{array}$ & $\begin{array}{l}>110 \% ; 100-110 \% \\
<100 \%\end{array}$ & $1 ; 0.5 ; 0$ & 123 & 1 \\
\hline $\begin{array}{l}\text { Dynamics in the number of small-size business } \\
\text { members of the cluster }\end{array}$ & $\begin{array}{l}>110 \% ; 100-110 \% \\
<100 \%\end{array}$ & $1 ; 0.5 ; 0$ & 118 & 1 \\
\hline Coefficient of the cluster industries localization & $>2 ;<2$ & $1 ; 0$ & $3 / 8$ & 1 \\
\hline \multicolumn{5}{|c|}{ No synergistic effect from interaction } \\
\hline $\begin{array}{l}\text { Market position coefficient for the final cluster } \\
\text { product }\end{array}$ & $\begin{array}{l}0.81-1.0 ; 0.51-0.8 ; 0.1- \\
0.5\end{array}$ & $1 ; 0.5 ; 0$ & 0.64 & 0.5 \\
\hline Percentage of the cluster market & $>0.7 ; 0.4-0.7 ;<0.4$ & $1 ; 0.5 ; 0$ & 0.51 & 0.5 \\
\hline $\begin{array}{l}\text { Dynamics of the indicator of the cluster } \\
\text { synergistic effect** }\end{array}$ & $\begin{array}{l}>110 \% ; 100-110 \% \\
\quad<100 \%\end{array}$ & $1 ; 0.5 ; 0$ & 98 & 0 \\
\hline
\end{tabular}




\begin{tabular}{lcccc}
\hline $\begin{array}{l}\text { Percentage of the cluster enterprises that } \\
\text { refused to participate in cluster projects over a } \\
\text { certain period of time }\end{array}$ & $<10 \% ; 10-50 \% ;>50 \%$ & $1 ; 0.5 ; 0$ & 25 & 0.5 \\
$\begin{array}{l}\text { Coefficient of satisfaction from cooperation in } \\
\text { the cluster** }\end{array}$ & $<0.1 ; 0.1-0.5 ;>0.5$ & $1 ; 0.5 ; 0$ & 0.6 & 0 \\
\hline Total & $\mathrm{x}$ & $\mathrm{x}$ & 0.56 \\
\hline Integral indicator for integration security (JIs)
\end{tabular}

*The cluster synergistic effect indicator can be determined using a cost-based approach in the form of the difference between the total market value of the cluster member enterprises before and after they became cluster members.

${ }^{* *} \mathrm{~A}$ ratio of the number of cluster members that found the cooperation to be unsatisfactory in relation to their total number (determined based on a survey or expert assessments).

The low value obtained in the example of the calculation of the integration safety integral indicator seen in Table 1 shows that the level of cluster management should be increased. The lowest indicator values confirm that all the enterprises interested in the cluster's development must exert effort to overcome some problems.

Table 2 presents a number of parameters, their indicators, and an example of the calculation of the integrated indicator for managemental security of the cluster management level. The figures seen in the cluster management safety integrated indicator calculation example show a rather high level of cluster management performance.

Table 2 Composition of values and their indicators for managemental security of the cluster management level

\begin{tabular}{|c|c|c|c|c|}
\hline Indicator's name & Threshold value & $\begin{array}{c}\text { Indicator's } \\
\text { value }\end{array}$ & $\begin{array}{c}\text { Actual } \\
\text { indicator }\end{array}$ & Indicator \\
\hline \multicolumn{5}{|c|}{ Type of threat to economic security } \\
\hline \multicolumn{5}{|c|}{ Inefficiency of management of a cluster } \\
\hline $\begin{array}{l}\text { Existence of an approved Cluster } \\
\text { Development Program (strategy) }\end{array}$ & Yes; No & $1 ; 0$ & yes & 1 \\
\hline Regular meetings of cluster members & Yes; No & $1 ; 0$ & yes & 1 \\
\hline Number of initiated cluster projects & $>125 \% ; 100-125 \% ;<100 \%$ & $1 ; 0.5 ; 0$ & 135 & 1 \\
\hline $\begin{array}{l}\text { Implementation of the cluster brand } \\
\text { promotion program }\end{array}$ & Yes; No & $1 ; 0$ & yes & 1 \\
\hline \multicolumn{5}{|c|}{ Lack of coordination of cluster participation in the projects and programs at the regional and federal levels } \\
\hline $\begin{array}{l}\text { Dynamics in the cluster's projects that are } \\
\text { implemented }\end{array}$ & $>125 \% ; 100-125 \% ;<100 \%$ & $1 ; 0.5 ; 0$ & 80 & 0 \\
\hline $\begin{array}{l}\text { Percentage of the projects that were granted } \\
\text { state support }\end{array}$ & $>70 \% ; 40-70 \% ;<40 \%$ & $1 ; 0.5 ; 0$ & 75 & 1 \\
\hline $\begin{array}{l}\text { Dynamics in funding the cluster projects that } \\
\text { are implemented }\end{array}$ & $>110 \% ; 100-110 \% ;<100 \%$ & $1 ; 0.5 ; 0$ & 125 & 1 \\
\hline \multicolumn{5}{|c|}{ Cluster managers' lack of experience in managing the integrated associations } \\
\hline $\begin{array}{l}\text { Percentage of the cluster's management staff } \\
\text { with less than } 3 \text { years of work experience }\end{array}$ & $>50 \% ; 10-50 \% ;<10 \%$ & $1 ; 0.5 ; 0$ & 60 & 1 \\
\hline $\begin{array}{l}\text { Percentage of the cluster's management staff } \\
\text { who completed internships (increased their } \\
\text { qualifications) }\end{array}$ & $>50 \% ; 10-50 \% ;<10 \%$ & $1 ; 0.5 ; 0$ & 25 & 0.5 \\
\hline \multicolumn{5}{|c|}{ Ineffective control and monitoring of the cluster policy implementation/Failure to develop a cluster performance scorecard } \\
\hline $\begin{array}{l}\text { Regular reporting meetings held by cluster } \\
\text { managers }\end{array}$ & Yes; No & $1 ; 0$ & yes & 1 \\
\hline $\begin{array}{l}\text { Development of the Cluster Program } \\
\text { Implementation Indicator System }\end{array}$ & Yes; No & $1 ; 0$ & no & 0 \\
\hline $\begin{array}{l}\text { Development of a cluster performance } \\
\text { scorecard }\end{array}$ & Yes; No & $1 ; 0$ & yes & 1 \\
\hline Total & $\mathrm{x}$ & $\mathrm{x}$ & $\mathrm{x}$ & 9.5 \\
\hline \multicolumn{3}{|c|}{ Managemental security integral indicator (JMS) } & \multicolumn{2}{|c|}{0.79} \\
\hline
\end{tabular}

The low values of the indicators presented in Table 2 show that it is necessary to intensify the effort to bring all the initiated cluster projects to the stage at which they can 
be implemented and to develop a system of indicators that would enable assessing the degree to which the Cluster Program was fulfilled.

All this should be done with the purpose of strengthening the control functions of the cluster management staff.

Table 3 presents a number of parameters, their indicators, and an example of the calculation of the integrated indicator for the personnel security of the cluster management level.

Table 3 Composition of the values and their indicators for the personnel security of the cluster management level

\begin{tabular}{|c|c|c|c|c|}
\hline Indicator's name & Threshold value & $\begin{array}{c}\text { Indicator's } \\
\text { value }\end{array}$ & $\begin{array}{c}\text { Actual } \\
\text { indicator }\end{array}$ & Indicator \\
\hline \multicolumn{5}{|c|}{ Type of threat to economic security } \\
\hline \multicolumn{5}{|c|}{ Lack of qualified professional managers } \\
\hline $\begin{array}{l}\text { Dynamics in the ratio of the cluster's managerial } \\
\text { personnel }\end{array}$ & $\begin{array}{c}>110 \% ; 100-110 \% \\
<100 \%\end{array}$ & $1 ; 0.5 ; 0$ & 140 & 1 \\
\hline $\begin{array}{l}\text { Percentage of the cluster's management staff with } \\
\text { less than } 3 \text { years of work experience }\end{array}$ & $>70 \% ; 11-70 \% ;<10 \%$ & $1 ; 0.5 ; 0$ & 70 & 0.5 \\
\hline $\begin{array}{l}\text { Percentage of the cluster's management staff who } \\
\text { completed internships (increased their } \\
\text { qualifications) }\end{array}$ & $<10 \% ; 11-50 \% ;>50 \%$ & $1 ; 0.5 ; 0$ & 25 & 0.5 \\
\hline \multicolumn{5}{|c|}{ Loss and solicitation of qualified personnel by competitors } \\
\hline $\begin{array}{l}\text { Percentage of the qualified personnel who crossed } \\
\text { over to competitors }\end{array}$ & $<5 \% ; 5-20 \% ;>20 \%$ & $1 ; 0.5 ; 0$ & 10 & 0.5 \\
\hline $\begin{array}{l}\text { Percentage of the qualified personnel who retired } \\
\text { for other reasons }\end{array}$ & $<5 \% ; 5-20 \% ;>20 \%$ & $1 ; 0.5 ; 0$ & 15 & 0.5 \\
\hline \multicolumn{5}{|c|}{ Low effectiveness of the cluster's human resources (HR) recruitment policy } \\
\hline Turnover rate dynamics & $\begin{array}{l}<100 \% ; 100-110 \% \\
>110 \%\end{array}$ & $1 ; 0.5 ; 0$ & 125 & 0 \\
\hline Dynamics of vacancy time & $\begin{array}{l}<100 \% ; 100-110 \% \\
\quad>110 \%\end{array}$ & $1 ; 0.5 ; 0$ & 105 & 0.5 \\
\hline Percentage of filled vacancies & $>90 \% ; 70-90 \% ;<70 \%$ & $1 ; 0.5 ; 0$ & 80 & 0.5 \\
\hline $\begin{array}{l}\text { Implementation of the policy on the retention of } \\
\text { qualified personnel }\end{array}$ & Yes; No & $1 ; 0$ & no & 0 \\
\hline Total & $\mathrm{x}$ & $\mathrm{x}$ & $\mathrm{x}$ & 4 \\
\hline \multicolumn{3}{|c|}{ Personnel security integral indicator (JPS) } & \multicolumn{2}{|c|}{0.44} \\
\hline
\end{tabular}

The example of calculating the indicators is presented in such a way that demonstrates a situation when there is a problem with the personnel security in the cluster (Table 3). Moreover, we showed the threats to economic security in terms of the qualifications of the managers in the cluster's managemental system and in terms of the availability of qualified personnel. This situation can be corrected by developing and implementing the cluster's effective personnel policy, directed at the attraction and retention of personnel in the organizations participating in the cluster.

Table 4 presents the composition of the values, their indicators, and an example of the calculation of the integral indicator for the financial and investment security of the cluster management level. The example data show a rather high level of financial and investment security in the cluster. With that said, the economic security indicators demonstrate that the main tasks of the cluster's managers are to find opportunities for attracting the necessary borrowed resources by the participating enterprises of the cluster and to monitor compliance with the planned parameters of the cluster projects in order to ensure their effectiveness.

Table 5 presents the composition of the values, their indicators, and the example of a calculation of the integrated indicator for information security of the cluster management level. 
Table 4 Composition of the values and their indicators for the financial and investment security of the cluster management level

\begin{tabular}{|c|c|c|c|c|}
\hline Indicator's name & Threshold value & $\begin{array}{l}\text { Indicator's } \\
\text { value }\end{array}$ & $\begin{array}{c}\text { Actual } \\
\text { indicator }\end{array}$ & Indicator \\
\hline \multicolumn{5}{|c|}{ Type of threat to economic security } \\
\hline \multicolumn{5}{|c|}{ Choosing erroneous priorities for funding the cluster policy activities } \\
\hline $\begin{array}{l}\text { Availability of the developed criteria to assess } \\
\text { the performance and effectiveness of the } \\
\text { cluster projects }\end{array}$ & Yes; No & $1 ; 0$ & yes & 1 \\
\hline $\begin{array}{l}\text { Application of a project approach to determine } \\
\text { the funding levels for the cluster projects }\end{array}$ & Yes; No & $1 ; 0$ & yes & 1 \\
\hline $\begin{array}{l}\text { The use of competitive mechanisms to support } \\
\text { the cluster projects }\end{array}$ & Yes; No & $1 ; 0$ & yes & 1 \\
\hline \multicolumn{5}{|c|}{ Inaccessibility of credit resources } \\
\hline $\begin{array}{l}\text { Percentage of the cluster participant } \\
\text { enterprises with low creditability }\end{array}$ & $<20 \% ; 20-50 \% ;>50 \%$ & $1 ; 0.5 ; 0$ & 40 & 0.5 \\
\hline $\begin{array}{l}\text { Percentage of the cluster participant } \\
\text { enterprises that do not have a collateral base }\end{array}$ & $<20 \% ; 20-50 \% ;>50 \%$ & $1 ; 0.5 ; 0$ & 30 & 0.5 \\
\hline $\begin{array}{l}\text { Availability of state guarantees for obtaining } \\
\text { loans from the microfinance fund for small-size } \\
\text { enterprises participating in the cluster }\end{array}$ & Yes; No & $1 ; 0$ & yes & 1 \\
\hline \multicolumn{5}{|c|}{ Investment unattractiveness of the cluster projects } \\
\hline $\begin{array}{l}\text { Dynamics in the volume of the cluster projects } \\
\text { financing carried out by external investors }\end{array}$ & $>110 \% ; 100-110 \% ;<100 \%$ & $1 ; 0.5 ; 0$ & 115 & 1 \\
\hline $\begin{array}{l}\text { Percentage of the cluster projects realized with } \\
\text { a profitability lower than planned }\end{array}$ & $<20 \% ; 20-50 \% ;>50 \%$ & $1 ; 0.5 ; 0$ & 30 & 0.5 \\
\hline $\begin{array}{l}\text { Implementation of the investment resource } \\
\text { mobilization policy }\end{array}$ & Yes; No & $1 ; 0$ & yes & 1 \\
\hline Total & $\mathrm{x}$ & $\mathrm{x}$ & $\mathrm{x}$ & 7.5 \\
\hline \multicolumn{3}{|c|}{ Integral indicator for financial and investment security (JFIS) } & \multicolumn{2}{|c|}{0.83} \\
\hline
\end{tabular}

Table 5 Composition of the values and their indicators for information security of the cluster management level

\begin{tabular}{|c|c|c|c|c|}
\hline Indicator's name & Threshold value & $\begin{array}{c}\text { Indicator's } \\
\text { value }\end{array}$ & $\begin{array}{c}\text { Actual } \\
\text { indicator }\end{array}$ & Indicator \\
\hline \multicolumn{5}{|c|}{ Type of threat to economic security } \\
\hline \multicolumn{5}{|c|}{ Violation of the rules for using communication channels for information transfer in the cluster } \\
\hline $\begin{array}{l}\text { Maintenance of a separate database of the } \\
\text { cluster }\end{array}$ & Yes; No & $1 ; 0$ & yes & 1 \\
\hline $\begin{array}{l}\text { Meeting the requirements for personal data } \\
\text { protection }\end{array}$ & Yes; No & $1 ; 0$ & yes & 1 \\
\hline $\begin{array}{l}\text { Percentage of the licensed software used to } \\
\text { transfer information in the cluster }\end{array}$ & $>90 \% ; 70-90 \%$; <70\% & $1 ; 0.5 ; 0$ & 85 & 0.5 \\
\hline \multicolumn{5}{|c|}{ Loss of strategic plans and technologies (industrial espionage) } \\
\hline $\begin{array}{l}\text { Different levels of employee access to } \\
\text { information containing commercial secrets }\end{array}$ & Yes; No & $1 ; 0$ & no & 0 \\
\hline $\begin{array}{l}\text { There is a security system for the interaction } \\
\text { among the cluster members in the confidential } \\
\text { data transfer sphere }\end{array}$ & Yes; No & $1 ; 0$ & no & 0 \\
\hline $\begin{array}{l}\text { Record-keeping of any user's activity in the } \\
\text { cluster with the files containing confidential } \\
\text { information }\end{array}$ & Yes; No & $1 ; 0$ & no & 0 \\
\hline \multicolumn{5}{|c|}{ Loss of access to information resources (loss of "links") } \\
\hline $\begin{array}{l}\text { The presence of officials in the cluster that are } \\
\text { responsible for ensuring information security }\end{array}$ & Yes; No & $1 ; 0$ & no & 0 \\
\hline $\begin{array}{l}\text { The use of reliable components for } \\
\text { communication networks in a cluster that } \\
\text { cannot unexpectedly fail and undermine the } \\
\text { system's health }\end{array}$ & Yes; No & $1 ; 0$ & no & 0 \\
\hline
\end{tabular}




\begin{tabular}{|c|c|c|c|c|}
\hline $\begin{array}{l}\text { Application of the tested software solutions, } \\
\text { the pros and cons of which are obvious }\end{array}$ & Yes; No & $1 ; 0$ & yes & 1 \\
\hline \multicolumn{5}{|c|}{$\begin{array}{c}\text { Disclosure of the information related to competitive advantages, technological capabilities, and cluster development } \\
\text { prospects }\end{array}$} \\
\hline $\begin{array}{l}\text { Dynamics in the number of cases of } \\
\text { unauthorized access to confidential } \\
\text { information }\end{array}$ & $\begin{array}{c}<100 \% ; 100-110 \% \\
>110 \%\end{array}$ & $1 ; 0.5 ; 0$ & 120 & 0 \\
\hline $\begin{array}{l}\text { Availability of a system of layered information } \\
\text { defense with several lines of protection }\end{array}$ & Yes; No & $1 ; 0$ & no & 0 \\
\hline Total & $\mathrm{x}$ & $\mathrm{x}$ & $x$ & 3.5 \\
\hline \multicolumn{3}{|c|}{ Integrated indicator for information security $\left(\mathrm{J}_{\mathrm{IFS}}\right)$} & \multicolumn{2}{|c|}{0.32} \\
\hline
\end{tabular}

The example of the calculation of the integrated indicator for information security given in Table 5 demonstrates its very low level, which points at the potential threats to a loss or a deliberate transfer of confidential information to competitors, as well as the insufficient reliability of the used communication channels between the cluster members.

This situation has to attract the cluster managers' attention to the development and implementation of specific organizational and technical measures required to protect information in the interests of all the cluster members. The reliability of information protection in the current conditions will contribute to the growth of confidence in the interactions among the cluster members.

Maintaining the necessary level of economic security in the cluster is possible when using the latest technologies, updating and modernizing the technical equipment of the cluster member-enterprises, and ensuring the transfer of innovations among them. Table 6 presents the composition of the values, their indicators, and an example of the calculation of the integral indicators for innovation safety.

Table 6 Composition of the values and their indicators for the innovation safety of the cluster management level

\begin{tabular}{|c|c|c|c|c|}
\hline Indicator's name & Threshold value & $\begin{array}{c}\text { Indicator's } \\
\text { value }\end{array}$ & $\begin{array}{c}\text { Actual } \\
\text { indicator }\end{array}$ & Indicator \\
\hline \multicolumn{5}{|c|}{ Type of threat to economic security } \\
\hline \multicolumn{5}{|c|}{ Insufficient innovations in the cluster (lack of new knowledge production centers) } \\
\hline $\begin{array}{l}\text { Dynamics in research and development (R\& D) } \\
\text { volumes of all the cluster participants }\end{array}$ & $>110 \% ; 100-110 \% ;<100 \%$ & $1 ; 0.5 ; 0$ & 125 & 1 \\
\hline $\begin{array}{l}\text { Percentage of innovative products in the total } \\
\text { volume of cluster products }\end{array}$ & $>80 \% ; 50-90 \% ;<50 \%$ & $1 ; 0.5 ; 0$ & 75 & 0.5 \\
\hline $\begin{array}{l}\text { Dynamics in the number of cluster participants } \\
\text { that carry our R\&D cluster }\end{array}$ & $>110 \% ; 100-110 \% ;<100 \%$ & $1 ; 0.5 ; 0$ & 110 & 0.5 \\
\hline $\begin{array}{l}\text { Availability of a privately-owned technological } \\
\text { park }\end{array}$ & Yes; No & $1 ; 0$ & no & 0 \\
\hline \multicolumn{5}{|c|}{ Undeveloped external and internal scientific and technological relations } \\
\hline $\begin{array}{l}\text { Dynamics in the number of cluster projects with } \\
\text { participation of scientific institutions }\end{array}$ & $>110 \% ; 100-110 \% ;<100 \%$ & $1 ; 0.5 ; 0$ & 110 & 0.5 \\
\hline $\begin{array}{l}\text { Availability of stable relations with an operating } \\
\text { technological park }\end{array}$ & Yes; No & $1 ; 0$ & no & 0 \\
\hline $\begin{array}{l}\text { Dynamics in the number of joint R\&D activities } \\
\text { performed by the cluster members }\end{array}$ & $>80 \% ; 50-90 \% ;<50 \%$ & $1 ; 0.5 ; 0$ & 125 & 1 \\
\hline \multicolumn{5}{|c|}{ No focus on the transfer of innovations among the cluster members } \\
\hline $\begin{array}{l}\text { Dynamics in the number of cluster participants } \\
\text { that implement innovations }\end{array}$ & $>110 \% ; 100-110 \% ;<100 \%$ & $1 ; 0.5 ; 0$ & 140 & 1 \\
\hline $\begin{array}{l}\text { Dynamics in the number of cluster members' } \\
\text { innovations transferred to other participants for } \\
\text { implementation }\end{array}$ & $>110 \% ; 100-110 \% ;<100 \%$ & $1 ; 0.5 ; 0$ & 125 & 1 \\
\hline $\begin{array}{l}\text { Implementation of the policy directed at involving } \\
\text { cluster members in the innovation process }\end{array}$ & Yes; No & $1 ; 0$ & yes & 1 \\
\hline Total & $\mathrm{x}$ & $\mathrm{x}$ & $\mathrm{x}$ & 6.5 \\
\hline \multicolumn{3}{|c|}{ Innovation security integral indicator (JINS) } & \multicolumn{2}{|c|}{0.65} \\
\hline
\end{tabular}


These examples are presented in such a way that one could conclude that there is a medium focus on innovations in the cluster development. To enhance the innovation level of the cluster, it is necessary to establish in-house centers for the production of new knowledge or to establish sustainable networks with existing technology parks or scientific institutions that develop the technologies that the enterprises in the cluster use to manufacture their products.

To define the total integral indicator of the level of the cluster structure (Jcluster level), the calculated integral indicators are summed up by the types of economic security:

$$
\text { Jcluster level }=\mathrm{J} \text { IS }+\mathrm{J} \text { MS }+\mathrm{J} \text { PS }+\mathrm{J} \text { FIS }+\mathrm{J} \text { IFS }+\mathrm{J} \text { INS }
$$

When calculating the total aggregate integral indicator for the level of economic security of the cluster (Jcluster ES), the total integral indicators for the level of the cluster structure and the level of enterprises, participating in the cluster. are summed up.

$$
\text { Jcluster ES }=\text { Jcluster level }+J_{\text {cluster participant level }}
$$

For a quantitative and qualitative assessment of the value of the aggregated integral parameter of the level of economic security of a cluster (Jcluster ES), it is possible to use a rating-and-score method.

If the total integral indicator for the cluster economic security level (Jcluster ES) is within 12 points (proceeding from the number of the designated types of economic security of the cluster association's levels and a maximum possible integral indicator score for economic security types in the amount of 1), four gradations of economic security levels can be distinguished (Table 7). If necessary, more detailed levels of economic security can be identified.

Table 7 Cluster economic security assessment criteria

\begin{tabular}{cll}
\hline $\begin{array}{l}\text { Value of } \\
\text { Jcluster ES }\end{array}$ & $\begin{array}{c}\text { Economic } \\
\text { security } \\
\text { level }\end{array}$ \\
\hline $10-12$ & high & $\begin{array}{l}\text { There is a low level of impact of threats on the economic security of the cluster. Managers } \\
\text { of the cluster implement an effective policy to counteract threats to the cluster's } \\
\text { economic security. }\end{array}$ \\
\hline $7-9$ & satisfactory & $\begin{array}{l}\text { There is an average level of impact of threats on the economic security of the cluster. } \\
\text { Managers of the cluster implement a policy of counteracting the threats to economic } \\
\text { security, which should be adjusted. }\end{array}$ \\
\hline $4-6$ & crises & $\begin{array}{l}\text { There is a high level of impact of threats on the economic security of the cluster. } \\
\text { Managers of the cluster implement an ineffective policy to counteract threats to } \\
\text { economic security and this policy should be significantly reviewed. }\end{array}$ \\
\hline $0-3$ & $\begin{array}{l}\text { There is a very high level of impact of threats on the economic security of the cluster. } \\
\text { Managers of the cluster implement an ineffective policy to counteract threats to } \\
\text { economic security; this policy should be radically changed in terms of the development } \\
\text { of strategic, tactical, and operational measures aimed at ensuring the economic security } \\
\text { of the cluster. }\end{array}$ \\
\hline
\end{tabular}

The use of the criteria that we proposed for assessing the level of economic security of the cluster and the use of recommendations for its improvement is possible if a Cluster Association Development Program is developed and implemented with the purpose of ensuring that certain managerial decisions are made to strengthen the cluster's economic security. Our proposed approach, in comparison with the methods of other scholars (Polyutov, 2009; Gakashev, 2013; Ermolaev, 2014), makes it possible to establish the level of economic security of the entire cluster structure; it contains a set of indicators characterizing all aspects of the functioning of the cluster, and the results of the analysis of 
the level of economic security of the cluster are oriented on assessing the effectiveness of management of the cluster management structure.

\section{Conclusions}

Based on the information outlined above, it can be concluded that, nowadays, there is a lack of a consolidated scientifically-recognized concept for assessing the issues related to the economic security of clusters. Specifically, the problem of methodological support of an integrated assessment of the economic security, taking into account specific features of the cluster management structure based on levels, remains unaddressed. To some extent, this is due to the fact that, as a phenomenon, clusters have only recently become widespread in Russia; they are now at the stage of empiric mastery of the accumulated information and experience. Regarding the economic security of the state, regions, and enterprises, many scholars have already proposed significant scientific works. However, very few studies have addressed the economic security of clusters.

In this regard, we have proposed an approach for assessing the level of economic security of specific integrated structures, such as clusters. It consists of identifying individual types of economic security for each level of management in a cluster (the level of participants and the level of the cluster as a whole), developing a list of indicators that characterize the economic security of each level of management in a cluster, determining the indicators of economic security, comparing and analyzing the actual values of indicators with threshold values of indicators, identifying and analyzing the deviations obtained, ranking the actual levels of threats based on the threshold values, and determining the integral indicator of the economic security of a cluster. The article presents an example of the implementation of the proposed technique. In the practical activities of the cluster, the actual values of the indicators in the context of the types of economic security will be filled in by cluster managers based on the analysis of the results of its functioning. The data obtained by the cluster managers based on the proposed methodology make it possible to identify real and potential economic threats, find ways to level their consequences, and create and implement a program for the development of a cluster association that includes measures to strengthen the cluster's economic security.

\section{References}

Anderson, T., Serger, S., Sorvik, S., 2004. The Cluster Policies Whitebook. $1^{\text {st }}$ Edition. Sweden: IKED, Malmö

Afontsev, S.A., 2001. Discussion Problems of the Concept of National Economic Security. Russia XXI, Volume 2, pp. 60-66

Beaudry, C., Breschi, S., 2003. Are Firms in Clusters Really More Innovative? Economics of Innovation and New Technology, Volume 12(4), pp. 325-342

Buzan, B., 1991. New Patterns of Global Security in the Twenty-First Century. International Affairs, Volume 67(3), pp. 431-451

Delgado, M., Porter, M., Stern, S., 2014. Clusters, Convergence, and Economic Performance. Research Policy, Volume 43(10), pp. 1785-1799

Ermolaev, D.V., 2014. A Comprehensive Methodology for Assessing the State of Economic Security in the Formation of An Industrial Cluster. Bulletin of the Tula State University: Economic and legal sciences, Volume 1(1), pp. 183-192

Gakashev, M.M., 2013. Approaches to the Formation and Evaluation of the Effectiveness of Economic Clusters. Vector of science of Togliatti State University, Series: Economics and Management, Volume 1(12), pp. 25-27 
Izmalkova, I.V., Vertakova, Yu.V., 2019. Methodology of Complex Risk Diagnosis of Enterprises of a Cluster Structure. Economics and Management, Volume 5(163), pp. 6674

Jacobs, D., de Man, A.P., 1996. Cluster, Industrial Policy and Firm Strategy. Technology Analysis and Strategic Management, Volume 8(4), pp. 425-438

Klimonova, A.N., Yurina, E.A., 2014. Economic Security in the Context of Globalization: Threats and Opportunities. Social-Economic Phenomena and Processes, Volume 9(1), pp. 58-64

Kudrevich, V.V., Trilitskaya, O.Y., Pechak, Y.V., 2020 Actualization of Approaches to Assessing the Level of Economic Security of Enterprises. Regional Economics. South of Russia, Volume 8(1), pp. 234-243

Kudryavtseva, T., Kulagina, N., Lysenko, A., Berawi, M.A., Skhvediani, A., 2020. Developing Methods to Assess and Monitor Cluster Structures: The Case of Digital Clusters. International Journal of Technology, Volume 11(4), pp. 667-676

Lessman, C., 2013. Regional Inequality and Internal Conflict. In: CESifo $7^{\text {th }}$ Workshop on Political Economy 2013, CESifo Working Paper 4112

Malmberg, A., Power, D., 2005. How Do Firms in Clusters Create Knowledge? Industry and Innovation, Volume 12(4), pp. 409-431

Moeis, A.O., Desriani, F., Destyanto, A.R., Zagloel, T.Y., Hidayatno, A., Sutrisno, A., 2020. Sustainability Assessment of the Tanjung Priok Port Cluster. International Journal of Technology, Volume 11(2), pp. 353-363

Nanto, D., 2011. Economics and National Security: Issues and Implications for U.S. Policy. Report: Congressional Research Service, Library of Congress, Washington DC, USA

Nosov, A.L., 2018. Clusterization of the Economy and Economic Security of Business. Theories and Problems of Political Research, Volume 7(1), pp. 205-211

Plotnikov, V.A., 2015. Risks of the Implementation of Cluster Policy. Security Issues, Volume 2, pp. 8-24

Podmolodina, I.M., Voronin, V.P., Konovalova, E.M., 2012. Approaches to Assessing the Economic Security of Enterprises. Bulletin of the Voronezh State University of Engineering Technologies, Volume 4(54), pp. 156-161

Polyutov, A.A., 2009. Assessment of the Level of Economic Security of a Territorial Industrial Cluster. Transport Business in Russia, Volume 2, pp. 70-72

Porter, M.E., 1998. Clusters and Competition: New Agendas for Companies, Governments, and Institutions. In: Harvard Business Review. Boston, MA, USA: Harvard Business School

Roelandt, T., den Hertog, P., 1999. Cluster Analysis and Cluster Policy based on Strengthening Innovation: A Cluster Approach. In: Organiszation for Economic CoOperation and Development (OECD) Proceeding, OECD Publisher, Paris, France, pp. 926

Polyanin, A.V., Pronyaeva, L.I., Fedotenkova, O.A., 2018. Risk Management in Entrepreneurial Activity based on the Identification of Economic Threats. Knowledge Academy Bulletin, Volume 25(2), pp. 178-189

Senchagov, V.K., 2007. Economic Security of Russia. IVF, Volume 5(395), pp. 2-20

Sergeeva, I.A., Chunaev, S.Y., 2019. Analysis of Methodological Approaches to Assessing the Economic Security of an Enterprise. Modern Economics: Problems and Solutions, Volume 8, pp. 64-78

Sölvell, Ö., Lindqvist, G., Ketels, Ch., 2003. The Cluster Initiative Greenbook. $1^{\text {st }}$ Edition. Stockholm, Sweden: Ivory Tower 
Wennberg, K., Lindqvist, G., 2010. The Effect of Clusters on the Survival and Performance of New Firms. Small Business Economics, Volume 34(3), pp. 221-241

Wiratmadja, I.I., Govindaraju, R., Handayani, D., 2016. Innovation and Productivity in Indonesian it Clusters: The Influence of External Economies and Joint Action. International Journal of Technology, Volume 7(6), pp. 1097-1106 